\title{
Preparation and Antimicrobial Evaluation of Neem Oil Alkyd Resin and Its Application as Binder in Oil-Based Paint
}

\author{
Haruna Musa ${ }^{1} \&$ Sharif N. Usman ${ }^{2}$ \\ ${ }^{1}$ Department of Pure and Industrial Chemistry, Bayero University, Kano, Nigeria \\ ${ }^{2}$ Department of Chemical Sciences, Federal University Kashere, Gombe, Nigeria \\ Correspondence: Haruna Musa, Department of Pure and Industrial Chemistry, Bayero University, Kano, Nigeria. \\ E-mail: hmusa.chm@buk.edu.ng
}

\author{
Received: February 22, 2016 Accepted: March 17, 2016 Online Published: May 7, 2016 \\ doi:10.5539/enrr.v6n2p92 \\ URL: http://dx.doi.org/10.5539/enrr.v6n2p92
}

\begin{abstract}
Neem oil Alkyd resin (NOAR) was synthesized by alcoholysis and polycondensation using glycerol and phthalic anhydride respectively at $230-250^{\circ} \mathrm{C}$. The alkyd resin was characterized by FT-IR spectroscopy, viscometry, solubility in various solvents and antimicrobial activity against some selected bacterial species. FT-IR analyses indicated the successful synthesis of alkyd resin as also evident from titrimetric determination of acid number of the mixture which decreases as the reaction progresses. Microbiological analyses of the resin show that it is active against some selected bacterial specie particularly at concentrations of 100 and $50 \mathrm{mg} / \mathrm{ml}$ in DMSO. The synthesized resin was used as binder in the formulation of oil-based paints using varying resin concentration i.e. 0 , 10 , and $20 \% \mathrm{w} / \mathrm{v}$. The prepared paints were found to have excellent fastness properties to light, water, alkali but poor to xylene. The results obtained suggested that NOAR can serve as binder with potential applications in the production of antimicrobial paints.
\end{abstract}

Keywords: binder, Neem oil (NO), Neem oil alkyd resin (NOAR), paint

\section{Introduction}

In recent years there have been increasing demands for the application of natural products to address problems in the environment, in waste disposal, and in the depletion of non-renewable resources. Renewable resources can provide an interesting sustainable platform to substitute partially, and to some extent totally, petroleum-based polymers through the design of bio based polymers that can compete or even surpass the existing petroleum based materials on a cost-performance basis with a positive environmental impact (Lligadas, Ronda, Galia, \& Cadiz, 2013).Generally, there have been research interest aimed at harnessing various seeds oil for used in the chemical industries. The need is as result of ever increasing world demand for oil and challenges to expand the existing supplies of oils for human consumption and industrial utilization (Odetoye, Ogunniyi, \& Olatuji, 2008). Before, the cheaply supply of crude oil, vegetable oil have been used for painting and coating industries. But, trend has been spurred by depleted supply of fossil fuels, environmental issues and waste disposal problems (Derksen, Derksen, Pestrus, \& Peter, 1995).The current utilization of renewable raw material resources by chemical industries is $10-20 \%$ and it is expected to reach up to $25 \%$ by 2020 (Lucas, 2010). Polymer industries compel from its dependence on non-renewable sources and accept industrially applicable renewable sources (Meier \& Lucas, 2010). Undoubtedly, there is domination of crude oil by products but it does not limits the use of vegetable oils in the production of paints, inks, pharmaceuticals, cosmetics and chemical intermediates (Aigbodion \& Pillai 2000). Condensation polymerization reaction by which polyhydric alcohols and polybasic acid form polymers with resinous characteristics has long been known. In Nigeria, the demand of alkyd resin has increased over the years even though technical information on local production is scanty and large quantities of oils are always needed for the production of alkyd resin (Onukwli \& Igbokwe, 2008). Alkyd resins are widely used in the paint and coating industries and are formed by condensation reaction between polyalcohol and carboxylic acids (Blaise, Ogunniyi, Ongoka, Moussounga, \& Ouamba, 2012). Organic coatings are compatible to almost all materials, applied purposely to enhance appearance and protect the surface by the help of skeleton of resins (Johnsson \& Katarina, 2006). However, due to alkyd compatibility with many polymers made them suitable for the production of a very broad range of coating materials (Shaker, Alian, \& Elsawy, 2012). Paints could be described as colloidal mixture of chemical substances which when spread over a surface in a thin layer, form a solid, cohesive and adherent film. 
They are used in our daily life for decorative purposes as well as for protecting surface against various environmental effects like UV-radiation, chemical invasion, and mechanical stresses. A conventional paint consists of binder, pigment, solvent and additives. The polymer-binding material (alkyd resin) with a large extent of variation is responsible for the formation of continuous film that adheres to the substrate and holds the other substance together (Oladipo, Eromosele, \& Folarin, 2013).

\section{Material and Methods}

The Neem oil sample was obtained from National Research Institute for Chemical Technology (NARICT), Zaria, Nigeria. Glycerol, phthalic anhydride, white spirit, xylene, ethanol, methanol, Iron (III) oxide, calcium carbonate, calcium acetate were all obtained from Sigma Aldrich.

The apparatus and equipment used include: three-neck flask equipped with Dean and Stark apparatus, Reflux condenser, Brookfield Viscometer, Oswald Viscometer, suction filtration apparatus, $\mathrm{pH}$ meter Jenway model 3320, FTIR Spectrophotometre Agilent Technologies, and nitrogen source.

\subsection{Preparation of Alkyd Resin}

Monoglyceride was first prepared by heating a mixture of oil:glycerol (1:2 molar ratio) and $0.3 \mathrm{~g} \mathrm{CaCO}_{3}$ (catalyst) in a $500 \mathrm{ml}$ three necked round-bottom flask fitted with condenser, Dean and Stark apparatus. The mixture was heated to $240^{\circ} \mathrm{C}$ and maintained at this temperature for 2 hours. An aliquot was taken at interval to check for solubility in methanol which indicates the formation of the monoglyceride.

At the onset of the second phase, the temperature was lowered to about $180^{\circ} \mathrm{C}$ and measured quantity of phthalic anhydride (3:2 molar ratio of phthalic anhydride:glycerol) was added, followed by addition of xylene ( $10 \%$ of total weight charged) into the reaction mixture. The water of esterification evolved forms an azeotrope with xylene and removed at intervals. The temperature was increased to $230-250{ }^{\circ} \mathrm{C}$ while the reaction lasted. Aliquots were withdrawn from the reaction mixture at intervals of 60 minutes to determine the drop in acid value. The reaction was stopped when the acid value attained about $15 \mathrm{mg} \mathrm{KOH} / \mathrm{g}$ and the alkyd resin was allowed to cool (Onukwli \& Igbokwe, 2008).

The physicochemical parameters of NOAR such as colour, acid value and viscosity, were determined. The FTIR of the resin was acquired using FTIR (Agilent Technologies) while the antimicrobial properties were determined using well diffusion method.

\subsection{Reaction Scheme}

Alcoholysis stage:<smiles>[R]C(=O)OCC(COC([R])=O)OC([R])=O</smiles><smiles>[R]C(=O)OCC(CO)OC([R])=O</smiles>$$
\sim \% 98 \quad \sim \% 2
$$

scheme 1

Polyesterification stage:<smiles>[R]C(=O)OC(CO)CO</smiles><smiles></smiles><smiles>C#C[Si](C)(C)OC(C)=O</smiles><smiles>[R]C(=O)OCC(COC([Z])=O)OC([R])=O</smiles>

scheme 2 


\section{Results and Discussion}

The physical properties of the Neem oil sample were evaluated using standard methods of analyses and the resultsare presented in Table 1.

Table 1. Physico-Chemical Properties of Neem Oil

\begin{tabular}{ll}
\hline Physico-Chemical Properties & Neem Oil \\
\hline Colour & Golden yellow \\
Refractive index & 1.5301 \\
$\mathrm{pH}$ & 5.53 \\
Nature at room temperature & Liquid \\
Moisture content $(\%)$ & $0.05 \%$ \\
Specific gravity at $25^{\circ} \mathrm{C}\left(\mathrm{g} / \mathrm{cm}^{3}\right)$ & 0.9382 \\
Acid value $(\mathrm{mg} / \mathrm{g})$ & 1.980 \\
Iodine value $(\mathrm{mg} / \mathrm{g})$ & 69.780 \\
Saponification value $(\mathrm{mg} / \mathrm{g})$ & 176.30 \\
$\%$ FFA & 1.0 \\
Ester Value & 174.32 \\
\hline
\end{tabular}

The FT-IR spectra of the prepared NOAR exhibits a characteristic aromatic ring $\mathrm{C}=\mathrm{O}$ ester band at $1723 \mathrm{~cm}^{-1}$. The disappearance of O-H band in the range $3300-3500 \mathrm{~cm}^{-1}$ was observed in the NOAR. The peaks observed at 1601 and $1581 \mathrm{~cm}^{-1}$ indicates the presence of benzene ring in the resin arising from the reaction of monoglyceride and phthalic anhydride to form the alkyd resin.

The acid value was found to decrease progressively as in figure 1, which can be attributed to desperate reactivity of primary hydroxyl group (react at about $160^{\circ} \mathrm{C}$ ) and secondary hydroxyl group (react above $230^{\circ} \mathrm{C}$ ) with carboxylic group of phthalic anhydride. Also, the drop of acid value with time was linked to characteristics of step-growth polymerization process in which all the reactants were incorporated into the polymer chain. Similar observation was reported by (Onukwli \& Igbokwe, 2008). There was high evolution of water as in figure 2, followed by reduced rate at longer reaction period which was attributed to high initial esterification reaction resulted in condensation reaction. Similar result was reported by (Oladipo et al., 2013). It was also observed that the viscosity of the reaction mixture decreases as the reaction progresses.

Table 2. FTIR absorption frequencies of some key functional groups of Glycerol, NO and NOAR

\begin{tabular}{llll}
\hline Functional Group & $\mathrm{O}-\mathrm{H}$ & $-\mathrm{C}=\mathrm{O}$ & $\mathrm{C}-\mathrm{O}$ \\
\hline Glycerol & $3291.44 \mathrm{~cm}^{-1}$ & - & $1110,1032 \mathrm{~cm}^{-1}$ \\
NO & - & $1745.49 \mathrm{~cm}^{-1}$ & $1099.77 \mathrm{~cm}^{-1}$ \\
NOAR & - & $1723.29 \mathrm{~cm}^{-1}$ & $1071.37,1121.36 \mathrm{~cm}^{-1}$ \\
\hline
\end{tabular}

Table 3. Physical Properties of Neem Oil Alkyd Resin (NOAR)

\begin{tabular}{ll}
\hline Properties & Specific value \\
\hline Colour & Black \\
Viscosity $(\mathrm{Cp})$ & 1.34 \\
Solubility in; Xylene & Completely soluble \\
Turpentine & Completely soluble \\
Ethanol & Partially soluble \\
Methanol & Partially soluble \\
\hline
\end{tabular}




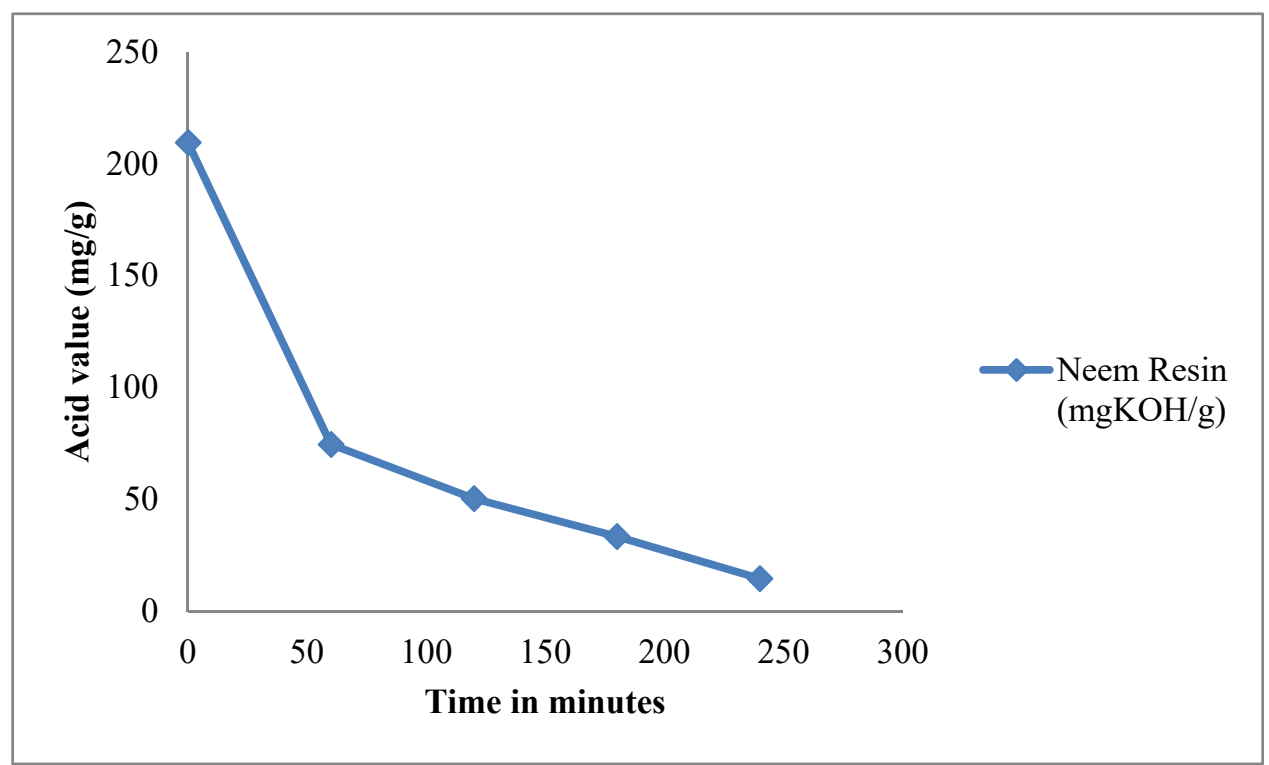

Figure 1. The drop of acid value with polycondensation time

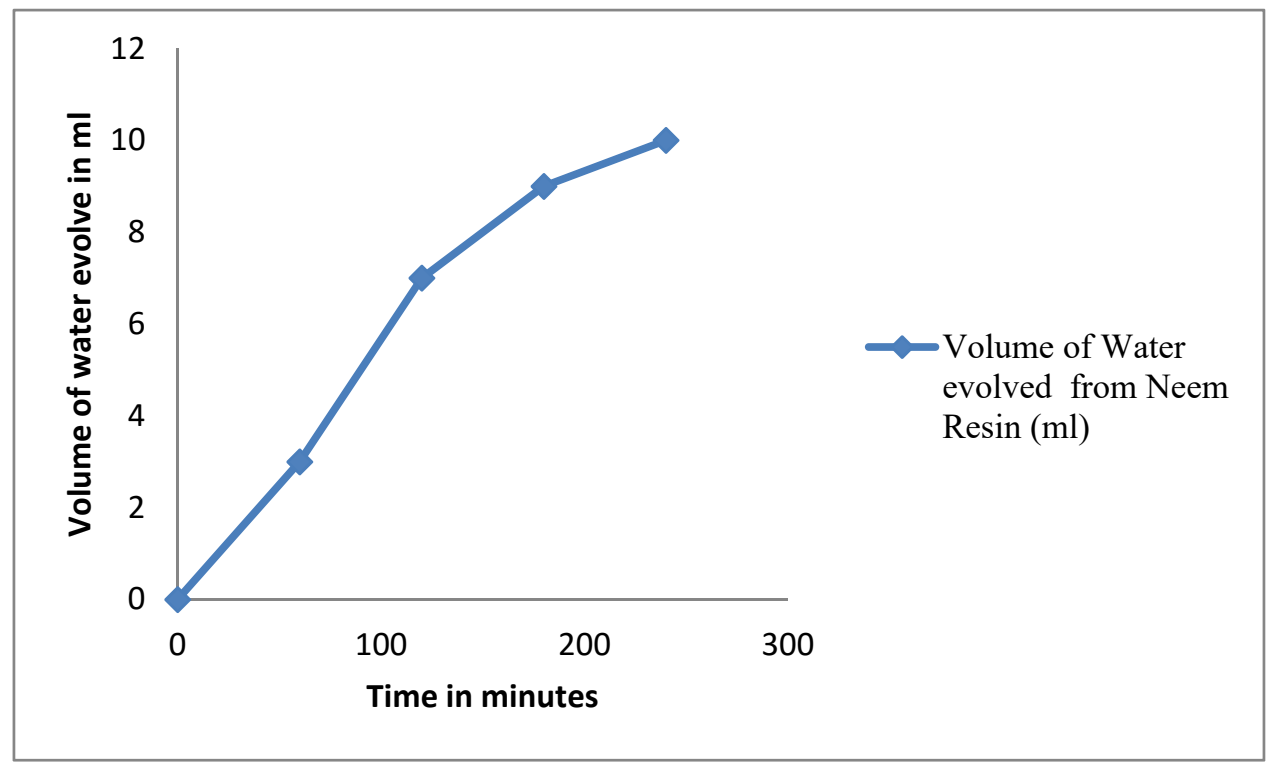

Figure 2. Volume of water evolved during synthesis of NOAR with reaction time

The Antimicrobial activity of NOAR was evaluated using well diffusion method of diameter $6 \mathrm{~mm}$ and the results obtained is presented in Table 4.

Table 4. Antimicrobial Activity of Neem Oil Alkyd Resin

\begin{tabular}{lllll}
\hline Isolates/Resin concentration & $100 \mathrm{mg} / \mathrm{ml}$ & $50 \mathrm{mg} / \mathrm{ml}$ & $25 \mathrm{mmg} / \mathrm{ml}$ & $2 \mathrm{mg} / \mathrm{ml}$ control \\
\hline Esterichia coli & 9 & 8 & 7 & 35 \\
Salmonella typhi & 12 & 10 & 7 & 32 \\
Staphylococcus aureus & 12 & 11 & 6 & 31 \\
\hline
\end{tabular}

* Control = Ciprofloxacin 
The NOAR show varying inhibition zone when tested against Escherichia coli, Salmonella typhi and Staphylococcus aureus bacterial species at various resin concentration. Also, the activity of NOAR was found to increase with increasing concentration.

In E.coli species, the inhibition zones are 9,8 and $7 \mathrm{~mm}$ when resin concentrations of $100 \mathrm{mg} / \mathrm{ml}, 50 \mathrm{mg} / \mathrm{ml}$ and $25 \mathrm{mg} / \mathrm{ml}$ respectively. Also, in Salmonella species the inhibition zones were 12,10 , and $7 \mathrm{~mm}$ at resin concentration of 100,50 and $25 \mathrm{mg} / \mathrm{ml}$ respectively. The resin was found to be active against Staphylococcus only at concentrations of 100 and $50 \mathrm{mg} / \mathrm{ml}$ and shows no activity (no observed change in well diameter) at $25 \mathrm{mg} / \mathrm{ml}$ resin concentration as presented in Table 4 .

\subsection{Paint Formulation}

An oil-based paint was formulated according to standard method reported by (Udeo, Umedum, Okoye \& Kelle, 2013). At first, $100 \mathrm{ml}$ of white spirit was measured, followed by dissolving measured quantity of resin $(0 \% \mathrm{w} / \mathrm{v}, 10 \%$ $\mathrm{w} / \mathrm{v}$, and $20 \% \mathrm{w} / \mathrm{v})$ and then mixed with stirring. Pigment $(15 \mathrm{~g})$ and 5 gram extender $\left(\mathrm{CaCO}_{3}\right)$ i.e. a ratio of 1:3 $\mathrm{w} / \mathrm{w}$ were added, followed by 0.3 gram of drying agent (calcium acetate). The mixture was then stirred for a period of one hour. The paint was then transferred and stored in an air tight container.

Table 5. Properties of Neem Oil Resin based Paint

\begin{tabular}{llll}
\hline Mechanical/Physical Test & $0 \%$ w/v NOAR & $10 \% \mathrm{w} / \mathrm{v}$ NOAR & $20 \% \mathrm{w} / \mathrm{v}$ NOAR \\
\hline Bending at $180^{\circ}$ (Flexibility test) & Crack Observed & No cracked observed & No cracked observed \\
Light Fastness Properties (At 94 hours) & 5 (Good) & 8 (Outstanding) & 8 (Outstanding) \\
Chemical Resistance; & & & \\
-Water & Good & Excellent & Excellent \\
-Salt $(\mathrm{NaCl})$ & Fair & Very Good & Very Good \\
-Acid $\left(\mathrm{H}_{2} \mathrm{SO}_{4}\right)$ & Fair & Good & Good \\
-Alkali $(\mathrm{NaOH})$ & Fair & Fair & Fair \\
- Xylene & Poor & Poor & Poor \\
Viscosity $(\mathrm{cp})$ & & 5.61 & 10.36 \\
\hline
\end{tabular}

The paints formulated were subjected to bending/flexibility test at $180^{\circ}$ in which the crack evidence was only observed at $0 \% \mathrm{w} / \mathrm{v}$ resin content paint. Also, the fastness to intense artificial UV-light source was found to be outstanding for $10 \%$ and $20 \% \mathrm{w} / \mathrm{v}$ resin paints but good for $0 \% \mathrm{w} / \mathrm{v}$ resin paint. The resistivity test of paints in different media shows an excellent resistance to water and very good resistance to brine but moderately to acid, alkali and very poor to xylene as seen in Table 5 .

\section{Conclusion}

Alkyds resin (NOAR) was successfully prepared using renewable, non-edible Neem Oil as raw material. Antimicrobial evaluation of the resin shows that it is active against Escherichia coli, Staphylococcus aureus and Salmonella typhi. The resin at various concentrations was employed as binder in the formulation of oil-based paints. The formulated paint containing NOAR as binder was found to have satisfactory properties in terms of flexibility, light fastness and resistance to water, acid and brine. The results obtained suggests the potentiality of Neem Oil bioresource in the preparation of NOAR that could have promising applications in the manufacture of antimicrobial surface coatings for use in schools, laboratories, hospitals and other public places.

\section{Acknowledgement}

The Authors would like to acknowledge Federal University Kashere, Gombe-Nigeria for granting study fellowship to Sharif N Usman to study MSc Polymer Chemistry at Bayero University Kano-Nigeria.

\section{Reference}

Aigbodion A. I., \& Pillai, C. S. K. (2000). Preparation, analysis and application of rubber seed oil and its derivatives in surface coatings. Progress in Organic Coatings, 38, 187-192.

Blaise V. I., Ogunniyi, D. S., Ongoka, P. R., Moussounga, J. E., \& Ouamba, J. M. (2012). Physicochemical properties of alkyds resin and palm oil blends. Malaysian Polymer Journal, 7(2), 42-45. 
Derksen, T. P. J., Pestrus, F. C., \& Peter, K. (1995). Renewable resources in coatings technology: a review. Progress in Organic Coatings, 27, 45-53.

Johansson M., \& Katarina, J. (2006). A model study on fatty acid methyl esters as reactive diluents in thermally cured coil coating systems. Progress in Organic Coatings, 55, 382-387.

Lligadas, G., Ronda, C. J., Galia, M., \& Cadiz, V. (2013). Renewable Polymeric Materials fromVegetable Oils; a perspective. Materials Today, 16(9), 337-343. http://dx.doi.org/10.1016/j.matto.2013.08.016

Lucas, E. M. (2010). Plant Oil as Renewable Precursors of Thermosetting and Flame Retardant Polymers (Unpublished doctoral dissertation). University Of Rovira I Virgili, Spain.

Meier A. R. M., \& Lucas, M. E. (2010). Plants oil: The Perfect Renewable Resource for Polymer Science, European Polymer Journal, 47, 837-852. http://dx.doi.org/10:1016/j.eurpolymj.2010.11.020

Nagehan, K. (2011). Synthesis and characterization of solvent free alkyd resin with hyperbranched melamine Core (Unpublished Masters thesis). Graduate School of Natural Sciences of Middle East Technical University.

Odetoye T. E., Ogunniyi, D., \& Olatuji, S. (2008). Vegetable oil as industrial raw material. Proceeding of the $1^{\text {st }}$ Kwara Conference of Chemical Society of Nigeria, 2008 Ilorin-Nigeria.

Oladipo, G. O., Eromosele, I. C., \& Folarin, O. M. (2013). Formation and Characterization of Paint Based on Alkyd Resin Derivative of Ximenia americana (wild olive) Seed Oil. Environmental and Natural Resources Research, 4(3), 52-62. http://dx.doi.org/10.5539/enrr.v3n3p52

Onukwli, O.D., \& Igbokwe, P. K. (2008). Production and Characterization of Castor Oil ModifiedAlkyd Resin. Journal of Engineering and Applied Sciences, 3(2),160-165.

Shaker, N. O., Alian, N. A., \& Elsawy, M. M. (2012). Preparation and Characterization and Evaluation of Jojoba seed oil modified alkyd resins. Pelagia Research Library, 3(5), 1157-1162.

Udeo, I. P., Umedum, N. L., Okoye, N. H., \& Kelle, I. H. (2013). Formulation of Glossy Emulsion Paint. Experimental Journal, 13(1), 822-828.

\section{Appendix A}

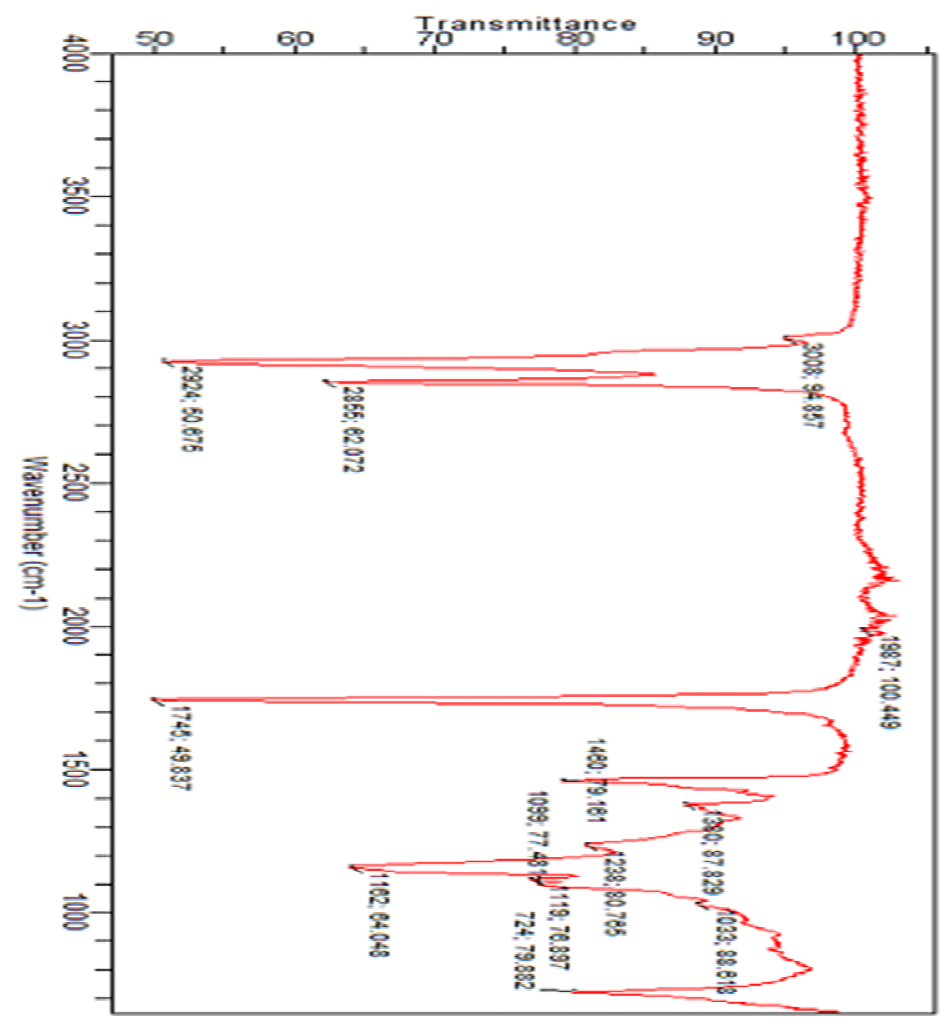

Neem Oil FT-IR Spectra 


\section{Appendix B}

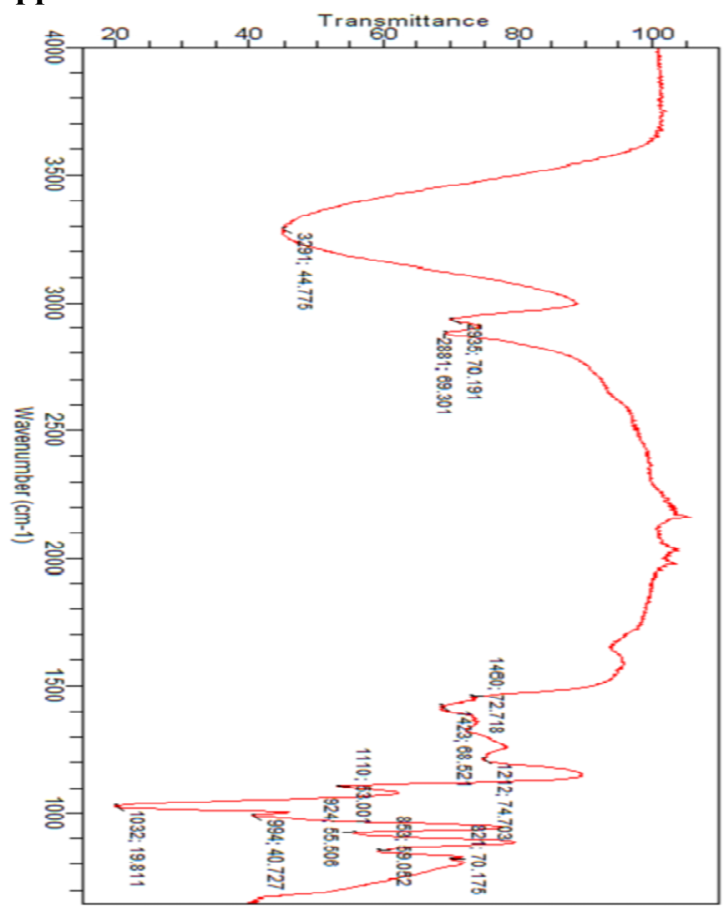

Glycerol FT-IR Spectrum

\section{Appendix C}

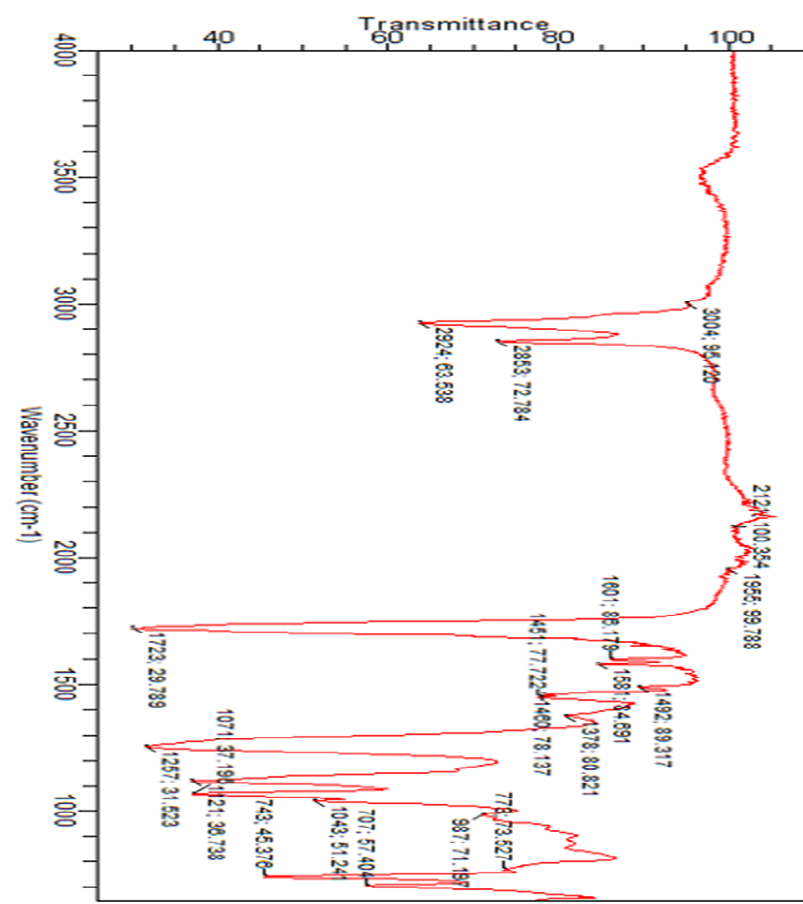

Neem Oil Alkyd Resin FT-IR Spectrum

\section{Copyrights}

Copyright for this article is retained by the author(s), with first publication rights granted to the journal.

This is an open-access article distributed under the terms and conditions of the Creative Commons Attribution license (http://creativecommons.org/licenses/by/3.0/). 